OPEN ACCESS

Edited by:

Urs Feller,

University of Bern, Switzerland

Reviewed by:

Jürgen Kreuzwieser,

Albert Ludwig University of Freiburg,

Germany

Bishal Gole Tamang,

University of Minnesota, USA

${ }^{*}$ Correspondence:

Afik Hardanto

ahardan@gwdg.de

Specialty section:

This article was submitted to Agroecology and Land Use Systems, a section of the journal Frontiers in Plant Science

Received: 12 January 2017 Accepted: 15 March 2017 Published: 03 April 2017

Citation: Hardanto A, Röll A, Niu F, Meijide A, Hendrayanto and Hölscher D (2017) Oil Palm and Rubber Tree Water Use

Patterns: Effects of Topography and Flooding. Front. Plant Sci. 8:452. doi: 10.3389/fpls.2017.00452

\section{Oil Palm and Rubber Tree Water Use Patterns: Effects of Topography and Flooding}

\author{
Afik Hardanto ${ }^{1,2 *}$, Alexander Röll ${ }^{1}$, Furong Niu ${ }^{1}$, Ana Meijide ${ }^{3}$, Hendrayanto $^{4}$ and \\ Dirk Hölscher ${ }^{1}$
}

${ }^{1}$ Tropical Silviculture and Forest Ecology, University of Göttingen, Göttingen, Germany, ${ }^{2}$ Faculty of Agriculture, Jenderal Soedirman University, Purwokerto, Indonesia, ${ }^{3}$ Bioclimatology, University of Göttingen, Göttingen, Germany, ${ }^{4}$ Faculty of Forestry, Bogor Agricultural University, Bogor, Indonesia

Oil palm and rubber plantations extend over large areas and encompass heterogeneous site conditions. In periods of high rainfall, plants in valleys and at riparian sites are more prone to flooding than plants at elevated topographic positions. We asked to what extent topographic position and flooding affect oil palm and rubber tree water use patterns and thereby influence spatial and temporal heterogeneity of transpiration. In an undulating terrain in the lowlands of Jambi, Indonesia, plantations of the two species were studied in plot pairs consisting of upland and adjacent valley plots. All upland plots were non-flooded, whereas the corresponding valley plots included non-flooded, longterm flooded, and short-term flooded conditions. Within each plot pair, sap flux densities in palms or trees were monitored simultaneously with thermal dissipation probes. In plot pairs with non-flooded valleys, sap flux densities of oil palms were only slightly different between the topographic positions, whereas sap flux densities of rubber trees were higher in the valley than at the according upland site. In pairs with long-term flooded valleys, sap flux densities in valleys were lower than at upland plots for both species, but the reduction was far less pronounced in oil palms than in rubber trees ( -22 and $-45 \%$ in maximum sap flux density, respectively). At these long-term flooded valley plots palm and tree water use also responded less sensitively to fluctuations in micrometeorological variables than at upland plots. In short-term flooded valley plots, sap flux densities of oil palm were hardly affected by flooding, but sap flux densities of rubber trees were reduced considerably. Topographic position and flooding thus affected water use patterns in both oil palms and rubber trees, but the changes in rubber trees were much more pronounced: compared to non-flooded upland sites, the different flooding conditions at valley sites amplified the observed heterogeneity of plot mean water use by a factor of 2.4 in oil palm and by a factor of 4.2 in rubber plantations. Such strong differences between species as well as the pronounced heterogeneity of water use across space and time may be of relevance for eco-hydrological assessments of tropical plantation landscapes.

Keywords: heterogeneity, Indonesia, sap flux, Sumatra, transpiration, variability 


\section{INTRODUCTION}

Oil palm (Elaeis guineensis Jacq.) and rubber (Hevea brasiliensis Müll. Arg.) plantations cover large areas in tropical regions (FAO, 2016) and are projected to expand further (Fox et al., 2012; Van der Laan et al., 2016). In contrast, the area covered by natural forests has strongly declined over the last decades (Keenan et al., 2015). From environmental perspectives, this raises concerns not only with respect to biodiversity (Barnes et al., 2014) but also regarding the integrity of the hydrological cycle including potential changes in transpiration (Ziegler et al., 2009; Sterling et al., 2012).

In previous studies, oil palm transpiration rates were analyzed on 15 on-farm plots in maritime Indonesia using a sap flux technique in conjunction with eddy covariance measurements at two sites (Röll et al., 2015; Meijide et al., 2017). Oil palm water use and transpiration increased from young to about 8year-old plantations and then leveled off up to an age of 22 years (Röll et al., 2015). Among medium-aged, 10-18 years old plantations substantial spatial heterogeneity was found. The highest oil palm stand (evapo) transpiration rates were observed in an intensively managed plantation; they were as high as those of rainforests in the same region (Röll et al., 2015; Meijide et al., 2017). It was also indicated that the temporal dynamics of transpiration in oil palm are "buffered," which means that dayto-day transpiration rates fluctuate less than micrometeorological drivers (Röll et al., 2015). For rubber plantations, previous studies reported relatively high evapotranspiration rates (i.e., partly higher than in adjacent natural forests) from China, Thailand, and Cambodia by means of eddy covariance measurements (Tan et al., 2011; Giambelluca et al., 2016). At the site in Cambodia, an experimental farm, both sap flux (Kobayashi et al., 2014) and eddy covariance measurements (Giambelluca et al., 2016) indicated that rubber tree transpiration responds sensitively to dynamics in radiation, air humidity and soil moisture.

In South East Asia and particularly Indonesia, oil palm and rubber plantations extend over large areas and thus commonly encompass heterogeneous sites. Vast parts of the Southeast Asian lowlands are actually not flat but undulating, separating into upland and valley sites (Miettinen et al., 2014). This leads to differences in soil moisture regimes: when rainfall is low, soil moisture availability for plants will be higher at valley sites (Sauer et al., 2005; Tromp-van Meerveld and McDonnell, 2006). Under prevailing high rainfall, plants in valleys and at riparian sites are often flooded for different durations, whereas plants at higher elevations on uplands sites are less prone to flooding (Deo et al., 2015).

In North-America, upland-to-wetland gradients were analyzed by means of sap flux measurements in order to evaluate the significance of site conditions for tree and stand transpiration (Loranty et al., 2008; Mackay et al., 2010; Angstmann et al., 2012). Pronounced differences in tree transpiration were observed among sites and it was concluded that it is necessary to include plots at different topographic positions for landscapelevel analyses or modeling of transpiration. Sap flux density and stand transpiration of Japanese cypress (Chamaecyparis obtusa) were significantly higher at valley than at upland sites (Kume et al., 2015), while being similar at both locations for Japanese cedar (Cryptomeria japonica) (Kumagai et al., 2008). For tropical rainforest regions such studies are still rare, but the influence of the water table on certain species was analyzed in northern Australia (McJannet, 2008) and Hawaii (Santiago et al., 2000). It was reported that waterlogging reduces transpiration of some species, while other species can adapt to this condition and were thus not or less affected. In tropical rainforests, tree species composition often differs between upland and periodically wet or riparian sites. Species on periodically wet or riparian sites (e.g., Melaleuca argentea W. Fitzg. and Corymbia bella Hill) may have the ability to transpire at high rates even during inundation due to adaptations, e.g... in the root system (O'Grady et al., 2006). In contrast, there is no difference in species composition across sites and topographic positions in monoculture plantations such as rubber and oil palm.

To our knowledge, whether, and if so to what extent landscape position and flooding induce spatial heterogeneity and temporal variability in transpiration rates of oil palms and rubber trees is so far unknown. Our study was implemented in the lowlands of Jambi province on Sumatra, Indonesia. The region is characterized by a steadily undulating topography (Gouyon et al., 1993; Whitten et al., 2000). Only a few decades ago, the region was largely covered by rainforests; today, it is dominated by oil palm and rubber plantations (Laumonier et al., 2010; Margono et al., 2012). Our objective was to determine to what extent topographic position and flooding affect oil palm and rubber tree water use patterns and thereby influence spatial and temporal heterogeneity of transpiration. The study may thus contribute to an improved eco-hydrological assessment of post-forest plantations landscapes in tropical lowlands.

\section{MATERIALS AND METHODS}

\section{Study Region}

The study was carried out close to the equator in the "Harapan region" of the lowlands of Jambi Province, Sumatra, Indonesia (Figure 1). Annual precipitation averages $2235 \mathrm{~mm}$ and average temperature is $26.7^{\circ} \mathrm{C}$ (Drescher et al., 2016). The terrain is undulating with altitudes varying between 40 and 100 masl at relatively short distance (Figure 1).

\section{Study Sites}

Our study comprised 12 plots in six plot pairs. For each plantation type, oil palm or rubber, we studied three plot pairs. Within each pair, one plot was situated at an upland site and the other at an adjacent valley site (Figure 2). The upland and valley sites were not more than $50 \mathrm{~m}$ apart. The upland plots were part of the general experimental design of the EFForTS project (Drescher et al., 2016; nomenclature: HO1, HO2, HO3 and HR1, HR2, HR3, where $\mathrm{H}$ stands for Harapan region, $\mathrm{O}$ for oil palm and $\mathrm{R}$ for rubber); the soil type at upland plots is loam Acrisol (Drescher et al., 2016). Valley sites have alluvial soils formed by accumulating eroded uphill soils. During the 

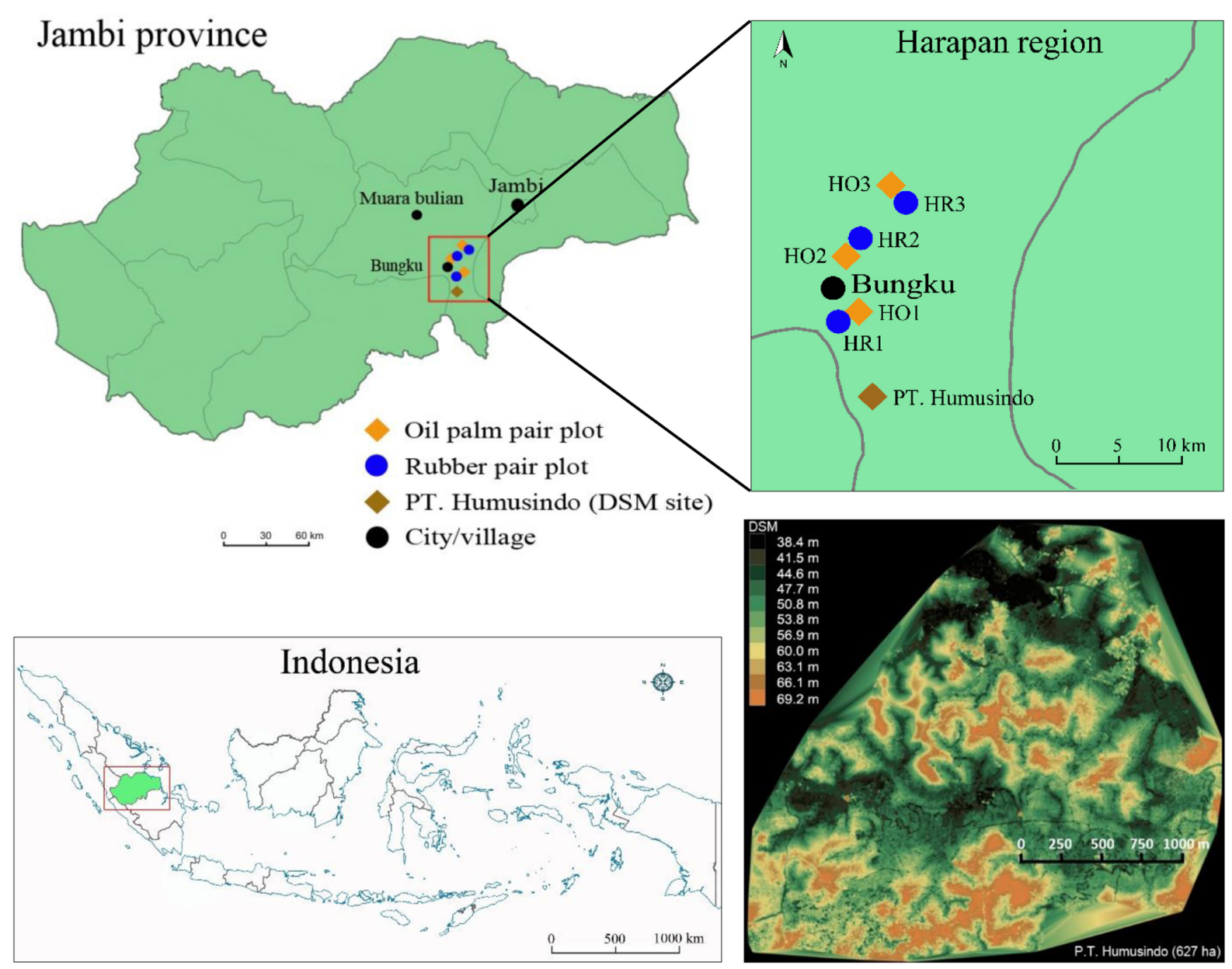

FIGURE 1 | The study region ("Harapan region") in Jambi Province, Sumatra, Indonesia. Location of oil palm and rubber plot pairs (each consisting of upland and valley sites). Upland sites were part of the larger experimental design of the EFForTS project (Drescher et al., 2016) and had plot codes $\mathrm{H}$ (for Harapan) with O for oil palm and R for rubber; numbering goes from South to North. The terrain of the landscape is undulating, as to be seen on a digital surface model (DSM, Naumann, 2015) of a 627 ha region in an oil palm plantation owned by P. T. Humusindo, approximately $10 \mathrm{~km}$ south of our study region (indicated by brown rhombus).

entire study period the upland plots were never flooded. During 4 -week measurement periods, the valley plots ranged from non-flooded over short-term flooded (4-5 days) to long-term flooded ( $>22$ days, Table 1). The plantations were between 14 and 18 years old. Stand densities tended to be higher at the upland sites, whereas diameters were similar between the corresponding upland and valley plots (Table 1). The plantations were owned and managed by local smallholders who, within a given plantation type, applied similar cultivation practices across sites.

\section{Sap Flux Measurements and Transpiration}

For each plot pair, sap flux densities $\left(J_{s}, \mathrm{~g} \mathrm{~cm}^{-2} \mathrm{~h}^{-1}\right)$ were measured simultaneously at upland and valley plots with Graniertype thermal dissipation probes (TDP, Granier, 1985) for at least 4 weeks. For oil palm, we followed the sampling and data processing procedure as described in Niu et al. (2015).
Four oil palms, each with four sensors inserted into individual leaf petioles, were equipped with TDPs. Specific calibration parameters were applied to calculate $J_{\mathrm{s}}$ (Niu et al., 2015) and leaf conductive areas $\left(\mathrm{cm}^{2}\right)$ were determined from a linear regression with petiole baseline length (Niu et al., 2015). To calculate palm water use rates (WU, $\mathrm{kg} \mathrm{day}^{-1}$ ), respective sap flux densities were multiplied by average leaf conductive areas and by the average number of leaves per palm. Multiplying the resulting average palm water use by the number of palms per unit of land yielded stand transpiration rates $\left(T ; \mathrm{mm} \mathrm{day}^{-1}\right)$. All $16 \mathrm{TDP}$ sensors of a certain oil palm plot running simultaneously would result in an error margin of estimated stand transpiration of oil palms of about $10 \%$ (Niu et al., 2015). This error is due to a limited sample size for both, establishing the average water conductive area per palm (by counting leaves and measuring petiole baseline length on a limited number of palms) and establishing average $J_{s}$ (with a limited number of TDP sensors running simultaneously). Stand transpiration as the product of stand water conductive area and $J_{\mathrm{s}}$ reflects both of these errors. 


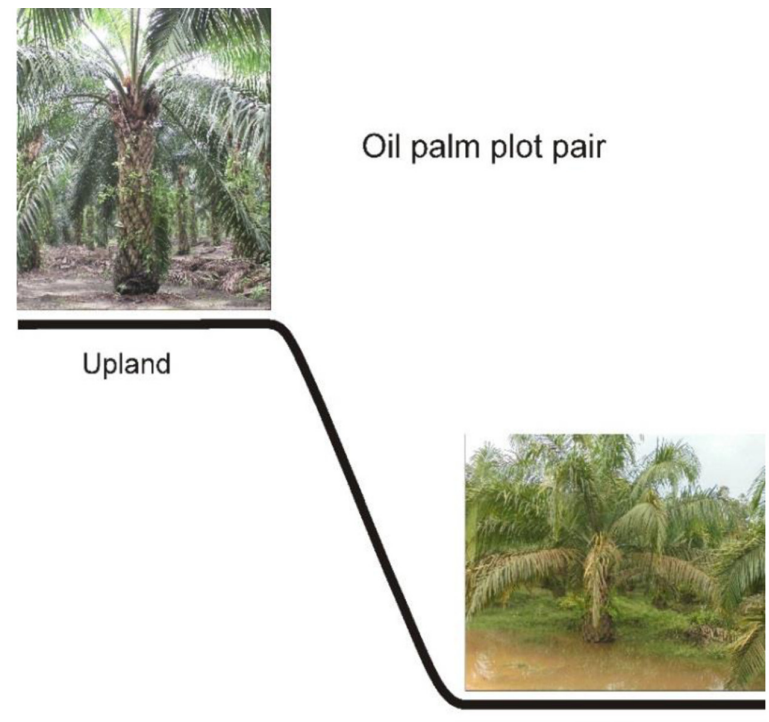

Valley

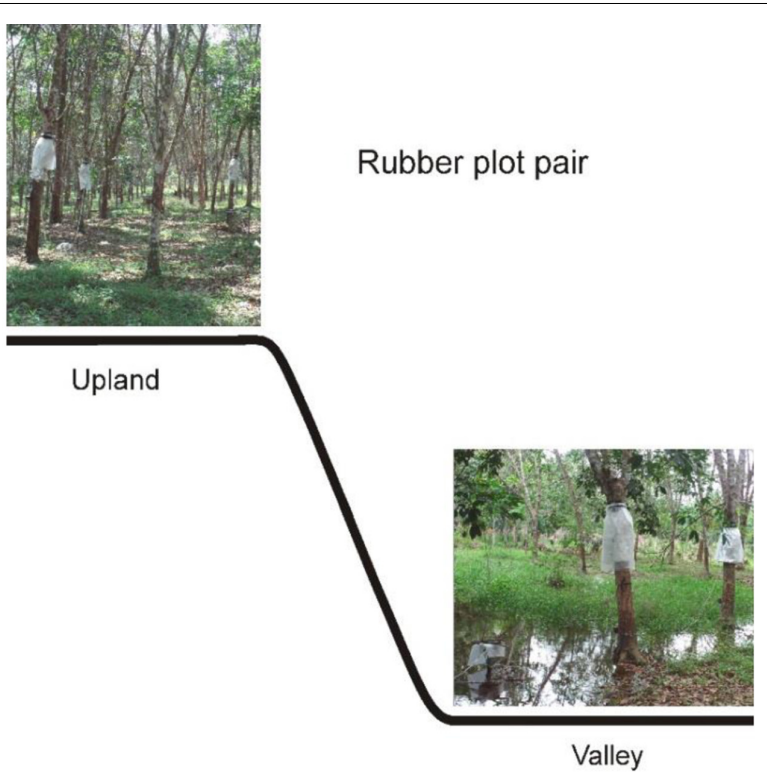

Valley

FIGURE 2 | In oil palm and rubber plantations, plot pairs consisting of upland and adjacent valley sites were studied, with three replicates for each plantation type. In the study period, the upland plots were never flooded, whereas the valley plots comprised non-flooded, long-term flooded, and short-term flooded conditions. Within each plot pair, sap flux measurements were conducted simultaneously at the upland and according valley site.

TABLE 1 | Stand characteristics and moisture conditions at the different topographic positions in oil palm and rubber plantations.

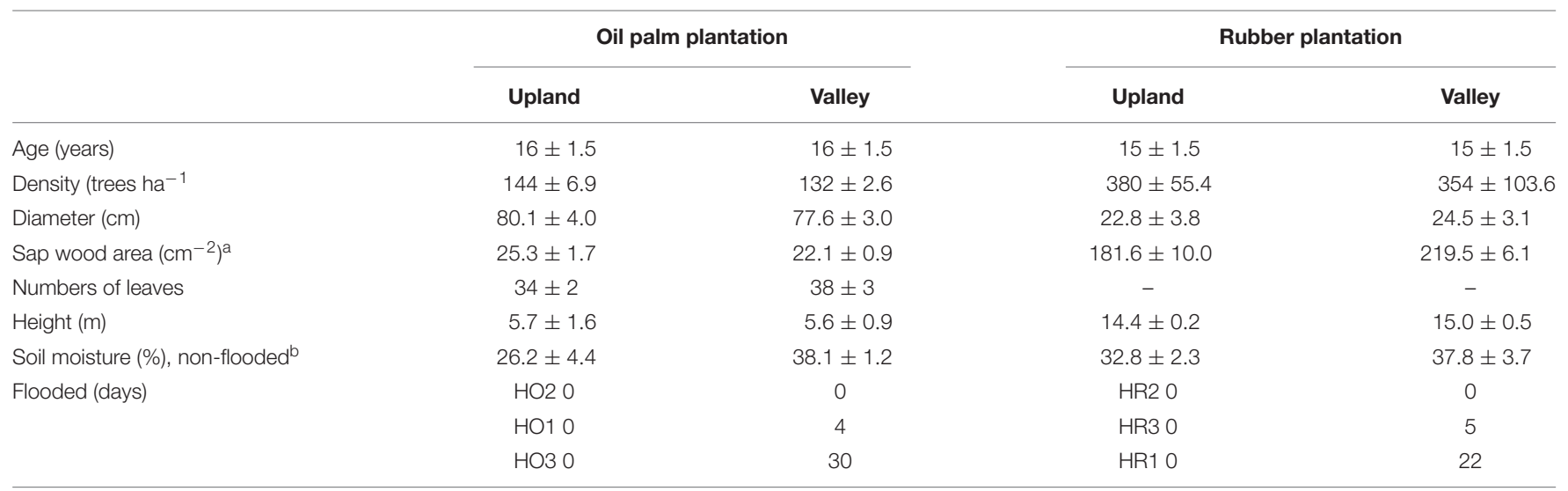

Means and standard errors, $n=3$.

aSap wood area of oil palm (average per leaf) and rubber trees (average per stem).

$\mathrm{b}_{n}=2$ for valley sites, mean of soil moisture at non-flooded oil palm (HO2) and rubber (HR2) valley sites and soil moisture at short-term flooded valley sites (HO1 and HR3) under non-flooded conditions. Short- and long-term flooded conditions are excluded.

For rubber trees, TDP sensors were installed on six trees per plot with two sensors per tree. The sensors were inserted above the latex harvesting area at a height of about 2-2.5 m. $J_{\mathrm{s}}$ was calculated using the original Granier (1985) equation, which was confirmed in a calibration experiment (Niu et al., unpublished). Recently established radial $J_{s}$ profiles accounting for changes in $J_{s}$ patterns with increasing xylem depth in rubber trees were applied (Niu et al., unpublished) to calculate tree water use $\left(\mathrm{kg} \mathrm{day}^{-1}\right)$. Using inventory data from the EFForTS project (stand density and tree diameters, Kotowska et al., 2015), stand transpiration rates could be calculated for the upland sites (see Niu et al., unpublished, for details); at adjacent valley sites, tree diameter and tree distance were recorded with a measurement tape. According to Kume et al. (2010) potential estimation errors in stand transpiration rates stem from both, a limited sample size (i.e., number of sensors) for establishing the average water conductive area and for establishing average $J_{s}$. For our rubber field measurement scheme, i.e., 12 sensors running simultaneously on six trees error margins of average $J_{\mathrm{s}}$ have been reported to be about 10\% (Kobayashi et al., 2014).

\section{Soil Water Content}

Soil water content was measured with time domain reflectometry (TDR) sensors (CS616, Campbell Scientific, UK). We installed eight TDRs per plot at two trees or palms, at 1 and $2 \mathrm{~m}$ distance from the trunk, and at two depths $(0-30$ and $30-60 \mathrm{~cm})$. 
Data were recorded hourly by a data logger (CR1000, Campbell Scientific, UK). Flooding was observed visually.

\section{Micrometeorological Variables}

Micrometeorological variables were monitored at a station about $10 \mathrm{~km}$ distant from our study plots in open terrain. Air temperature and humidity were measured by thermohygrometers (type 1.1025.55.000, Thies Clima, Germany) and were used to calculate vapor pressure deficit (VPD, $\mathrm{kPa}$ ).

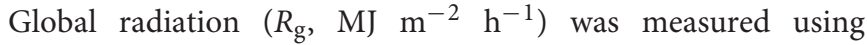
a CMP3 pyranometer (Kipp \& Zonen, Delf, Netherlands). Measurements were taken every $15 \mathrm{~s}$ and averaged and stored as 10 min values on a data logger (type DL16 Pro, Thies Clima, Germany).

\section{Data Analysis}

Even though 4-week data series of transpiration were available for each plot pair, results are presented mainly for selected sunny days (radiation $>17 \mathrm{MJ} \mathrm{m}^{-2}$ day $^{-1}$; VPD daytime average $>1.1 \mathrm{kPa}$ ) only. In the case of the short-term flooded plots, naturally only a few days of data were available under flooded conditions; to make these comparable to non-flooded or long-term flooded valley sites, we thus chose to focus on a sunny day only, in order to reduce influences of varying weather conditions among the different measurement periods. For plot pairs with non-flooded or long-term flooded valley sites, for which longer data series were available, the mean values of three sunny days were used to increase the robustness of the results. As most plot pairs were measured successively rather than simultaneously and thus potentially encompassed greatly varying weather conditions, using sunny days helped to focus the analysis on the spatial heterogeneity of (stand) transpiration as induced by flooding, rather than on the temporal day-to-day dynamics of transpiration.

Results are presented both as daily values and as diurnal hourly means; as a measure of the spatial, within-plot variability of $J_{s}$ and stand transpiration, standard errors (SE) of these values are provided; they were derived among all trees or palms within a certain plot (i.e., from 16 sensors on four oil palms or 12 sensors on six rubber trees, in analogy to Niu et al., 2015). Maximum $J_{\mathrm{s}}$ values $\left(J_{\text {smax }}\right)$ were derived from the 90-percentile of hourly $J_{\mathrm{s}}$ observations of the selected sunny days. Because of unequal variances, we used Welch's $t$-test to test for significant differences $(P<0.05)$ in $J_{\text {smax }}$ and average tree/palm water use within plot pairs, i.e., between upland and valley sites. Likewise, we used Welch's $t$-test (applicable for time repeated measurements) to test for differences between flooded and non-flooded conditions at the short-term flooded valley sites.

The day-to-day $J_{\mathrm{s}}$ responses to VPD and $R_{\mathrm{g}}$ were analyzed with a power function. Statistical analyses were performed with $\mathrm{R}$ version 3.0.2.

\section{RESULTS}

In the plot pairs with non-flooded valleys, oil palm $J_{s \max }$ and daily accumulated $J_{\mathrm{s}}$ were 4 and $12 \%$ higher in the valley than on the upland plot (Figure 3 and Table 2). The differences were more pronounced in the rubber plot pair; $J_{\text {smax }}$ and the daily accumulated $J_{\mathrm{s}}$ were 16 and 30\% higher in the valley (Figure 3 and Table 2). These differences go along with higher soil moisture contents at valley plots (oil palm: 28 vs. $37 \%$; rubber: 30 vs. $40 \%$, Table 1).

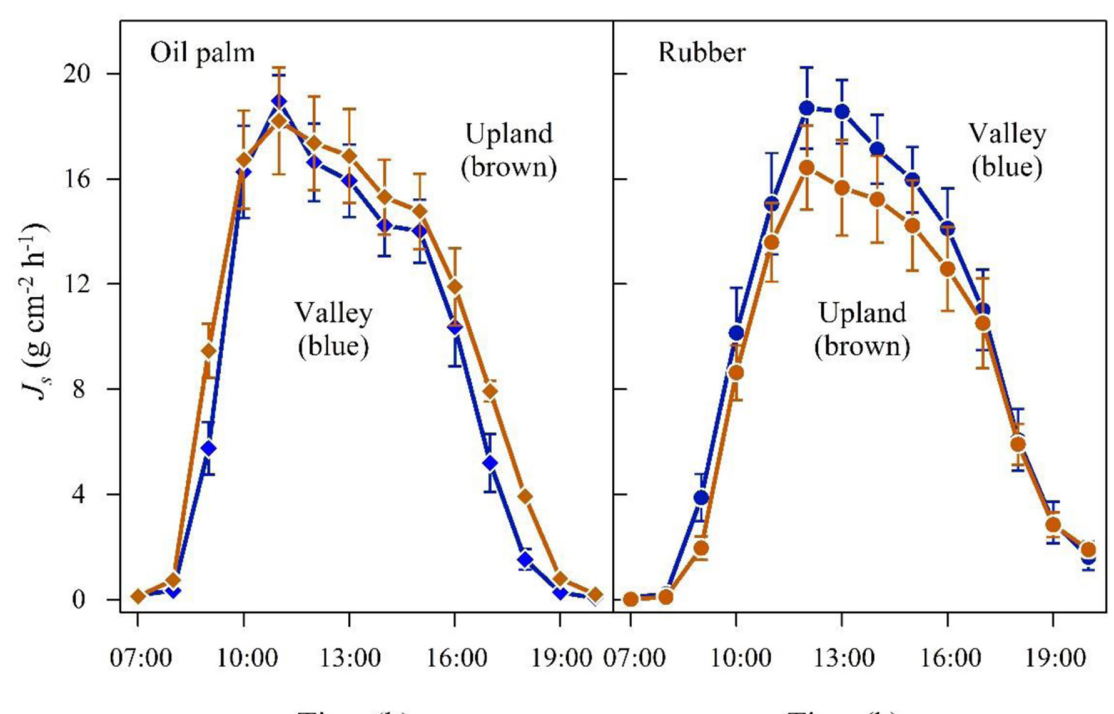

Time (h)

Time (h)

FIGURE 3 | Oil palm (left) and rubber (right) plot pairs with non-flooded valley. Diurnal course of sap flux density $\left(\mathrm{J}_{\mathrm{S}}\right)$ at the upland (brown) and corresponding non-flooded valley site (blue). Hourly means of three sunny days; vertical bars show the standard error of the mean in sap flux among rubber trees $(n=6$ trees; each with two sensors) and oil palms ( $n=4$ palms; each with four leaves and one sensor per leaf) in a plot at a given time. 
TABLE 2 | Maximum sap flux density $\left(J_{s m a x}\right)$ in oil palm leaf petioles and rubber tree trunks, water use per palm and tree and estimated stand transpiration rates at upland and valley plots under varying flooding conditions, i.e., non-flooded, long-term flooded, and short-term flooded (sunny days, means and standard errors).

\begin{tabular}{|c|c|c|c|c|c|c|}
\hline \multirow[t]{2}{*}{ Plot pair } & \multicolumn{3}{|c|}{ Oil palm } & \multicolumn{3}{|c|}{ Rubber } \\
\hline & $\begin{array}{c}J_{\mathrm{smax}} \\
\left(\mathrm{g} \mathrm{cm}^{-2} \mathrm{~h}^{-1}\right)\end{array}$ & $\begin{array}{l}\text { Water use } \\
\left(\mathbf{k g ~ d a y}^{-1}\right)\end{array}$ & $\begin{array}{l}\text { Transpiration } \\
\left(\mathbf{m m} \text { day }^{-1}\right)\end{array}$ & $\begin{array}{c}J_{\mathrm{smax}} \\
\left(\mathrm{g} \mathrm{cm}^{-2} \mathrm{~h}^{-1}\right)\end{array}$ & $\begin{array}{l}\text { Water use } \\
\left(\mathbf{k g ~ d a y}^{-1}\right)\end{array}$ & $\begin{array}{l}\text { Transpiration } \\
\left(\mathrm{mm} \text { day }^{-1}\right)\end{array}$ \\
\hline \multicolumn{7}{|l|}{ Valley non-flooded } \\
\hline Upland (HO2 and HR2) & $17.1 \pm 0.9$ & $94.8 \pm 4.5$ & 1.3 & $16.7 \pm 0.7$ & $26.6 \pm 3.2$ & 0.9 \\
\hline Valley & $17.7 \pm 0.9^{\text {ns } 1}$ & $94.7 \pm 4.6^{\mathrm{ns} 1}$ & 1.2 & $19.3 \pm 0.7^{\mathrm{ns} 1}$ & $33.2 \pm 2.5^{* 1}$ & 1.2 \\
\hline \multicolumn{7}{|l|}{ Valley long-term flooded } \\
\hline Upland (HO3 and HR1) & $14.8 \pm 0.5$ & $97.0 \pm 5.0$ & 1.4 & $15.3 \pm 1.0$ & $26.5 \pm 3.2$ & 0.9 \\
\hline Valley & $11.6 \pm 0.6^{* 1}$ & $63.0 \pm 2.0^{* 1}$ & 0.8 & $8.4 \pm 0.5^{* * 1}$ & $13.8 \pm 2.1^{* * 1}$ & 0.6 \\
\hline \multicolumn{7}{|l|}{ Valley short-term flooded } \\
\hline Upland (HO1 and HR3) & $13.6 \pm 0.5$ & $83.9 \pm 2.5$ & 1.2 & $17.8 \pm 0.6$ & $21.8 \pm 1.9$ & 1.0 \\
\hline \multicolumn{7}{|l|}{ Valley } \\
\hline 1. Non-flooded & $16.1 \pm 0.6^{\mathrm{ns} 2}$ & $81.3 \pm 3.9^{\text {ns2 }}$ & 1.1 & $21.3 \pm 0.9^{* 2}$ & $34.0 \pm 2.6^{* 2}$ & 0.9 \\
\hline 2. Flooded & $16.0 \pm 0.6$ & $82.7 \pm 3.5$ & 1.1 & $17.3 \pm 0.7$ & $27.8 \pm 2.1$ & 0.7 \\
\hline
\end{tabular}

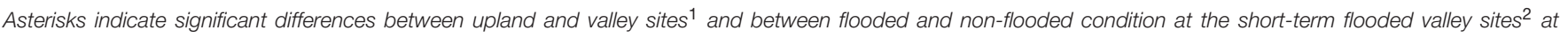
${ }^{*} P<0.05$ and ${ }^{* *} P<0.01 ; n s$, not significant, time repeated $t$-tests.

In the plot pairs with long-term flooded valleys, oil palm in the valley showed lower $J_{\mathrm{s}}$ than at upland plots (Figure 4). The $J_{s \max }$ in the valley was by $22 \%$ lower than on the upland plot (Table 2). A similar pattern was found in rubber trees, but again the difference was more pronounced $\left(J_{\text {smax }}-45 \%\right)$. Long-term flooding also influenced the day-to-day $J_{\mathrm{s}}$ response to changes in VPD and $R_{\mathrm{g}}$ : accumulated daily $J_{\mathrm{s}}$ generally increased with increasing VPD (Figure 5) and $R_{\mathrm{g}}$ (Figure 6) for both plantation types and flooding conditions, but the slopes of the regression equations were smaller in valleys than at upland sites, particularly for rubber (Figures 5, 6).
In the plot pair with short-term flooded valley, $J_{\mathrm{s}}$ in oil palm hardly responded to flooding (Figure 7 and Table 2). In contrast, $J_{\text {smax }}$ and daily accumulated $J_{s}$ in rubber were 19 and 22\% lower on a flooded day than on a non-flooded day, indicating a much more sensitive response to short-term flooding in rubber trees than in oil palms.

Overall, topographic position and flooding affected the heterogeneity of rubber tree and oil palm water use differently. The observed range of plot-averaged, normalized oil palm water use was 2.4-fold larger at valley sites than at upland sites, while for rubber trees, it was 4.2-fold larger at valley sites (Figure 8

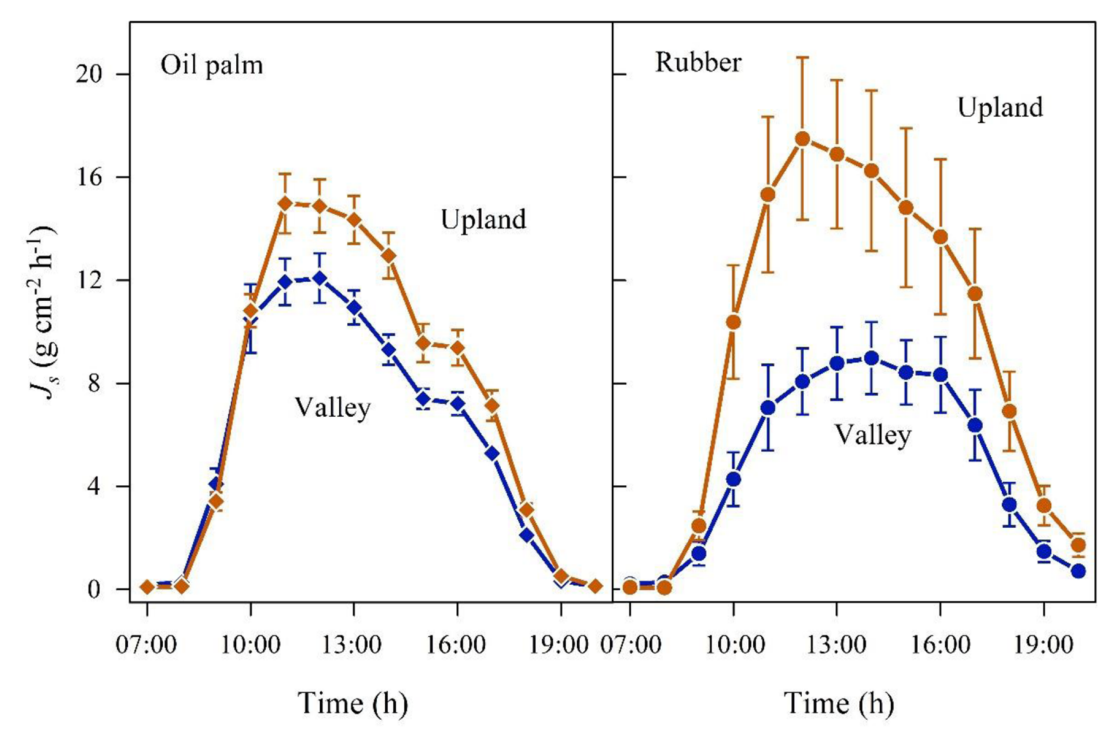

FIGURE 4 | Oil palm (left) and rubber (right) plot pairs with long-term flooded valley. Diurnal course of sap flux density $\left(J_{s}\right)$ at the upland (brown) and corresponding long-term flooded valley site (blue). Hourly means of three sunny days; vertical bars show the standard error of the mean in sap flux among rubber trees ( $n=6$ trees; each with two sensors) and oil palms ( $n=4$ palms; each with four leaves and one sensor per leaf) in a plot at a given time. 


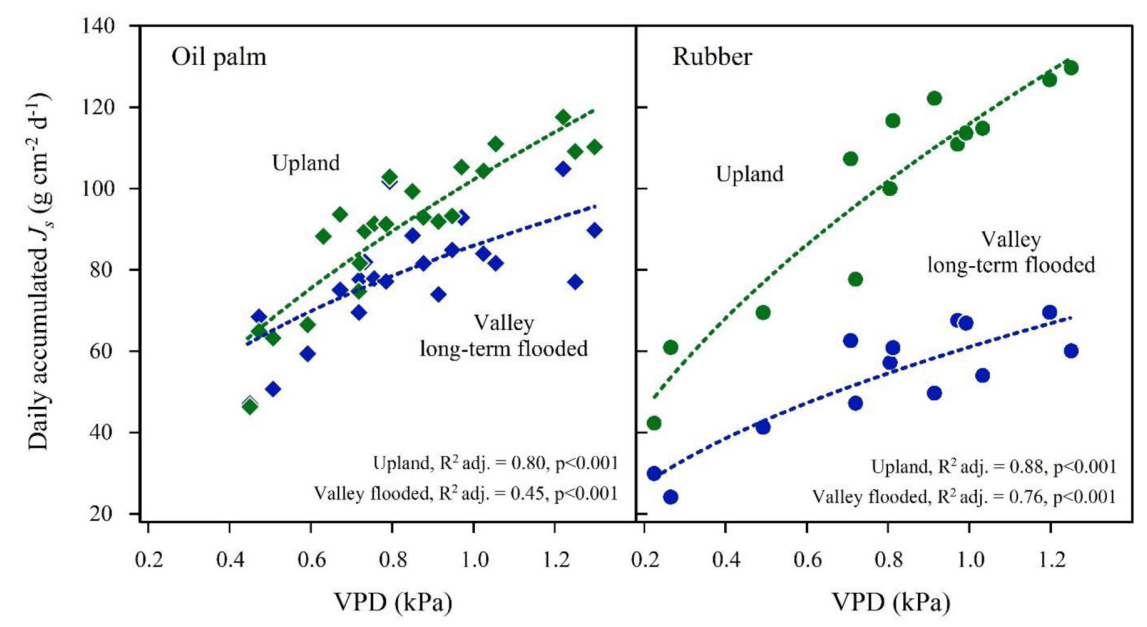

FIGURE 5 | Oil palm (left) and rubber (right) plot pairs with long-term flooded valley. Daily accumulated sap flux density $\left(J_{S}\right)$ in response to changes in average daily vapor pressure deficit (VPD) at the upland (green) and corresponding long-term flooded valley site (blue). Plot pairs were HO3 for oil palm and HR1 for rubber.

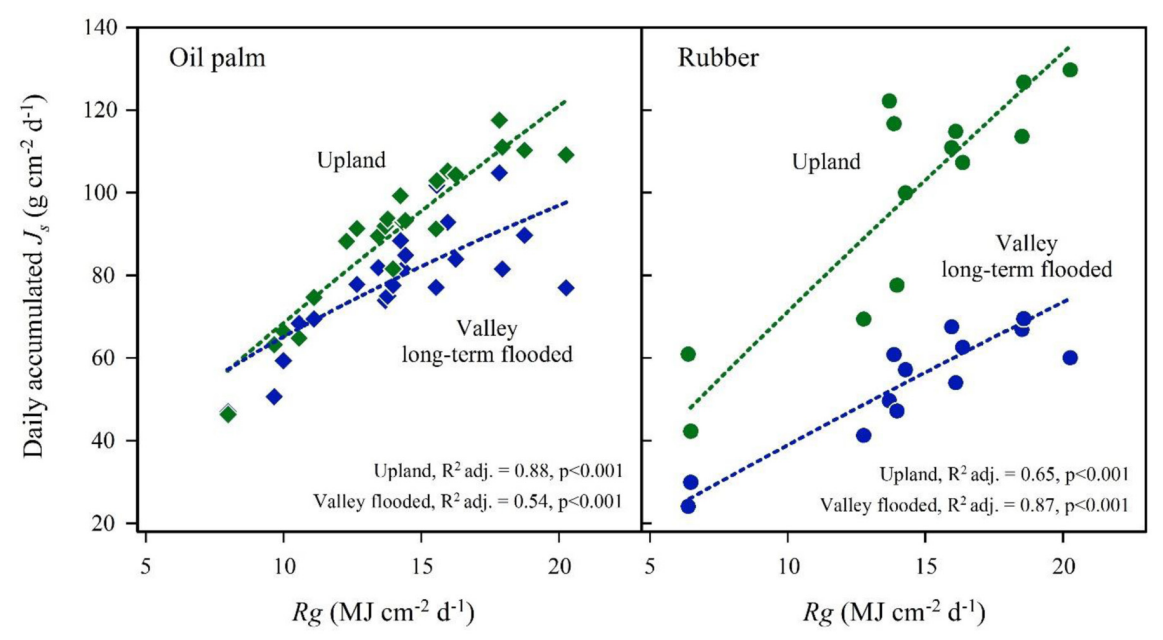

FIGURE 6 | Oil palm (left) and rubber (right) plot pairs with long-term flooded valley. Daily accumulated sap flux density ( $\left.J_{S}\right)$ in response to changes in global radiation day sums $\left(R_{g}\right)$ at the upland (green) and corresponding long-term flooded valley site (blue). Plot pairs were HO3 for oil palm and HR1 for rubber.

and Table 2). Translating these differences from the tree/palm level to patterns of transpiration estimates at the plot scale, i.e., taking into account differences in tree and palm densities and sizes between upland and valley sites, the heterogeneity of transpiration was increased by a factor of 2.3 from the upland to the valley in oil palm and by a factor of 12.5 in rubber plots (Figure 8 and Table 2).

\section{DISCUSSION}

In our study, topography and flooding induced substantial heterogeneity in plant water use. This was more pronounced in rubber trees than in oil palms. Our estimates of stand transpiration (0.6-1.2 $\mathrm{mm} \mathrm{day}^{-1}$ for rubber, $0.8-1.4 \mathrm{~mm} \mathrm{day}^{-1}$ for oil palm) were substantially lower than those reported for rubber plantations on the Asian mainland $\left(\sim 2 \mathrm{~mm} \mathrm{day}^{-1}\right.$, Isarangkool Na Ayutthaya et al., 2010; Kobayashi et al., 2014; Sopharat et al., 2015) and lower than those reported for an intensively managed oil palm plantation in the study region (2.5-2.7 mm day ${ }^{-1}$; Röll et al., 2015; Meijide et al., 2017). However, our oil palm estimate falls into the range of 1.1$2.5 \mathrm{~mm} \mathrm{day}^{-1}$ from a previous study in 12 productive oil palm plantations in the study region (including our three upland oil palm sites, Röll et al., 2015). Likewise, our rubber estimate compares to the mean of five-fully leaved, mature plantations in the study region (1.3 $\mathrm{mm} \mathrm{day}{ }^{-1}$, Niu et al., unpublished). Potential reasons for partly relatively large differences between our values and those reported in other studies include differences among methods with respect to the cited rubber studies, as 


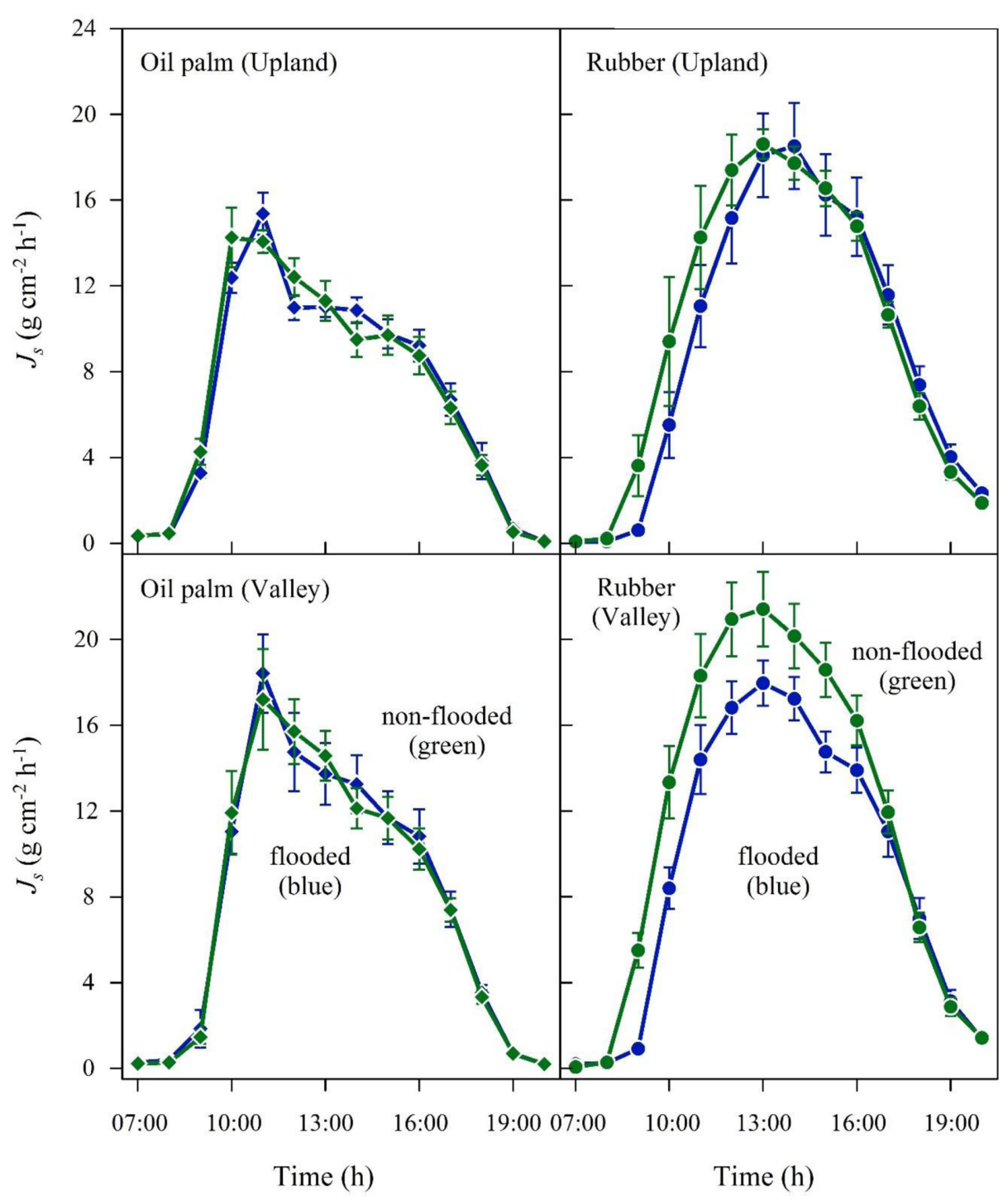

FIGURE 7 | Oil palm (left) and rubber (right) plot pairs with short-term flooded valley. Flooded and non-flooded conditions at the valley sites are compared. Diurnal course of sap flux density $\left(J_{S}\right)$ at upland (upper) and corresponding valley sites (lower). Upland sites were always non-flooded, but valley sites varied between non-flooded (green) and short-term flooded (blue) conditions. For the according periods (i.e., valley non-flooded, valley short-time flooded), upland $J_{s}$ as a reference is displayed separately (in green and blue, respectively). Hourly values on a sunny day; vertical bars show the standard error of the mean in sap flux among rubber trees ( $n=6$ trees; each with two sensors) and oil palms ( $n=4$ palms; each with four leaves and one sensor per leaf) in a plot at a given time.

well as different environmental site conditions and differences in management practices such as the utilization of varying clone types. In oil palm, our measurement approach has been calibrated (Niu et al., 2015) and yielded plausible results when compared to eddy covariance data (Röll et al., 2015). For rubber, no eddy covariance data was available for comparison, but conducted laboratory experiments and field assessments with different sap flux techniques showed no contradictions and give confidence that our approach is feasible (Niu et al., unpublished). Analyses of estimation uncertainties of water use rates due to limited sample size with our respective oil palm and rubber field measurement schemes point to potential uncertainties of mean water use of about 10\% (Kobayashi et al., 2014; Niu et al., 2015). However, and regardless of potential uncertainties in absolute water use rates of rubber trees and oil palms, this study was mainly designed to investigate relative differences in water use patterns between topographic positions and flooding conditions; to accurately quantify such relative differences in patterns is regarded a strength of sap flux approaches.

For both oil palms and rubber trees, $J_{\mathrm{s}}$ and plant water use were higher at non-flooded valley sites than at the corresponding upland sites. This was probably caused by more favorable soil moisture contents in valleys (i.e., higher, but not waterlogged, Table 1), which are likely due to run-off and drainage from 


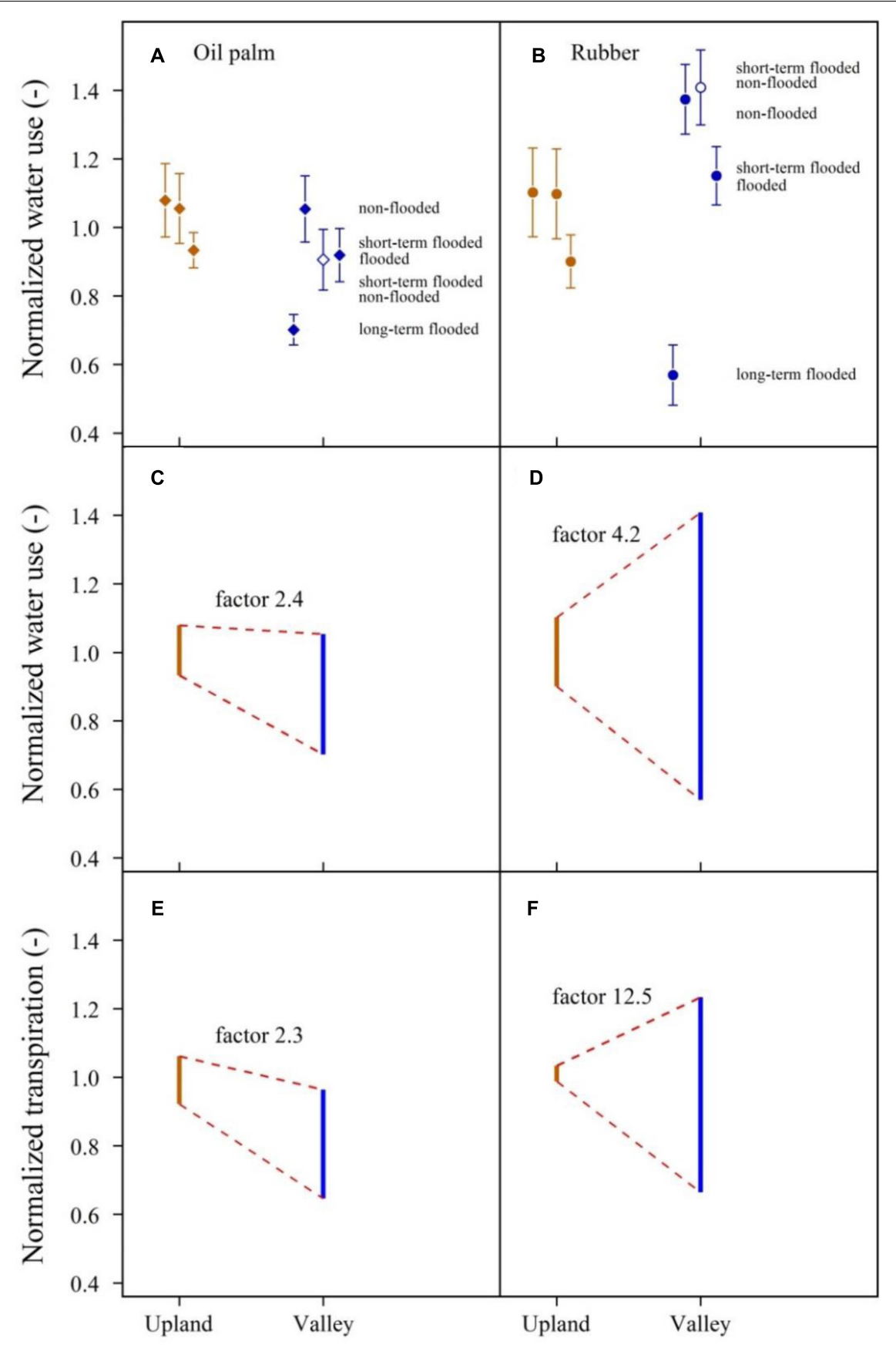

FIGURE 8 | Long-term, short-term, and non-flooded plot pairs combined. Water use by oil palm and rubber trees across upland and valley plots, normalized by mean oil palm (A) and rubber tree (B) water use on the upland plots (sunny days, means and standard errors). Short-term flooded valley plots are given twice, once under flooded (closed symbols) and once under non-flooded (open symbols) conditions. Dynamics of the heterogeneity of normalized water use (C,D) and normalized transpiration (E,F) of oil palm and rubber from upland to valley plots. Displayed factors quantify the heterogeneity that is induced as a result of topographic position and flooded conditions at valley sites in relation to the heterogeneity at upland sites.

adjacent slopes. In contrast, $J_{\mathrm{s}}$ and water use of both plantation types were lower than at upland plots in long-term flooded valleys. Floods reduce gaseous oxygen concentrations in soils and thus lead to hypoxic or anoxic conditions (Ezin et al., 2010; Wittmann and Pfanz, 2014). Root hydraulic conductivity and permeability are severely reduced (Else et al., 2001; Parent et al., 2008; Kreuzwieser and Rennenberg, 2014), which results in changes in leaf water potential, stomatal closure, and lower leafspecific hydraulic conductivity (Else et al., 2001; Atkinson et al., 2008; Herrera, 2013; Zhao et al., 2014). Consequently, plant water 
uptake is often substantially reduced under flooded conditions (Nicolás et al., 2005; Aroca et al., 2012; Yan et al., 2015). Longterm flooding can furthermore decrease water uptake capacities by injuring roots (Drew, 1997). For a scenario of frequent, longterm flooding, e.g., at riparian or valley sites, damages to the trunk induced by the frequent manual cutting for latex extraction could be enhanced, particularly at the trunk base. This could facilitate the entry of fungi and potentially reduce productivity and vitality of flood-prone rubber trees. However, flood-related mortality of rubber trees was not observed in the study region (personal observation); this is likely due to a combination of the relatively short rotation cycle of monoculture rubber plantations in the study region (approximately 20 years) and adaptions to regular flooding in the natural habitat of rubber (Amazonia). In accordance with the substantial decreases in the water use of oil palms $(-35 \%)$ and rubber trees $(-48 \%)$ under long-term flooded conditions in our study, decreases in water uptake under long-term flooded conditions were also pronounced in studies on other (tropical) species such as apricot $(\sim 15 \%)$, eucalyptus $(\sim 20 \%)$, and lemon $(\sim 50 \%)$ trees (Nicolás et al., 2005; Ortuño et al., 2007; Miyazawa et al., 2014).

Theoretically, lower (stand) transpiration of both plantation types under long-term flooded conditions could also be due to factors other than flooding, e.g., differences in site or stand characteristics. As the flooding periods at the long-term flooded valley sites exceeded the respective sap flux measurement periods, no data are available to evaluate stand transpiration under nonflooded conditions. However, the results from the short-term flooded plots for both oil palm and rubber (Figure 7) do not contradict the finding of lower transpiration as a result of long-term flooding. Further, the respective upland and valley sites of each plot pair (and thus including the pairs with long-term flooded valley) were located close to each other ( $<50 \mathrm{~m}$ distance), within the same (small-holder) plantations. Non-flooding related additional factors such as site, stand or management characteristics within plot pairs were thus relatively homogeneous and unlikely to be the dominant factor for low stand transpiration rates at long-term flooded valleys sites. Asides from the substantially reduced water use rates, the strong influence of long-term flooding on plant water use in our study is also visible in the less sensitive responses of $J_{s}$ to VPD and radiation (Figures 5, 6). These micrometeorological drivers were not measured above the canopy of each particular site but rather represent more general, open area upland conditions some kilometers from our sites. However, while variables such as air humidity and wind speed likely vary considerably between upland and valley sites even at short distance, radiation as an important driver of transpiration can be expected to vary far less due to the close proximity of our study sites to the equator. Keeping this in mind, our results indicate a more conservative response to environmental drivers at long-term flooded valley sites for both species, which may be related to reductions in root hydraulic conductivity and stomatal conductance. Substantial decreases in stomatal conductance were, e.g., reported for sweet gum (Liquidambar styraciflua L.), where it decreased by $24 \%$ after 1 day of flooding and by $70 \%$ after 9 days of flooding (Pezeshki and Chambers, 1985).
For all of the topographic positions and flooding conditions evaluated in this study, $J_{\mathrm{s}}$ and water use of rubber trees responded more sensitively than $J_{s}$ and water use of oil palms. Varying $J_{s}$ responses to flooded conditions between oil palm and rubber are in line with results from other studies, e.g., strong $J_{s}$ decreases in Eucalyptus camaldulensis, but no noticeable reductions of $J_{s}$ in the Shorea roxburghii and Dipterocarpus obtusifolius (Miyazawa et al., 2014). Likewise, $J_{s}$ was reported to be higher at valley sites than at upland sites for Japanese cypress (Kumagai et al., 2008), while being similar at both locations for Japanese cedar (Kume et al., 2015).

Such differences between species in their water use response to flooding are influenced by differences in plant morphology, particularly of the root and leaf system (Aroca et al., 2012; Kreuzwieser and Rennenberg, 2014; Miyazawa et al., 2014). Oil palm has a fibrous root system and its roots can spread over $6 \mathrm{~m}$ vertically and $25 \mathrm{~m}$ horizontally, while the rubber root system typically extends less (3-13 m) (Jourdan et al., 2000; Gonkhamdee, 2010). On an intra-annual basis, oil palms are not very dynamic in leaf area. The water use response of oil palms at upland sites to environmental drivers, in particular to air humidity, has been described as buffered (Röll et al., 2015). Based on hysteresis between water use and VPD, it was argued that internal stem water storage herein plays a role, as it had previously been observed in other palm species (Holbrook and Sinclair, 1992). In contrast to these attributes of oil palm, rubber trees at upland sites are quite responsive to dynamics of environmental drivers and shed their leaves during dry seasons (Kobayashi et al., 2014; Giambelluca et al., 2016), both of which enhances the heterogeneity of rubber water use across space and time. Within certain ranges, our findings thus point to and strengthen previous suggestions that oil palm water use is only moderately affected by environmental conditions including floods. In contrast, rubber tree water use is quite responsive to fluctuations in environmental conditions including short- and long-term flooding.

Both rubber and oil palm plantations cover large areas of the Sumatran lowlands, where they have replaced highly diverse natural forests. It, however, seems that the post-forest plantation landscape has more heterogeneous transpiration patterns than one might expect. This heterogeneity can partly be explained by the age class structure of the plantation landscape and by species differences in the response to environmental drivers including periodical leaf shedding in rubber (Röll et al., 2015; Niu et al., unpublished). As to how far different management schemes also play a role needs to be analyzed in more depth. Patterns described in Röll et al. (2015) suggest that high fertilizer input as mostly found in large estates leads to higher transpiration rates than in less intensively managed smallholder plantations. The present study adds yet another dimension to the plantation landscape by suggesting that topography and flooding are also strong factors influencing the heterogeneity of landscape-level transpiration patterns. Likewise, studies investigating uplandto-wetland gradients in North-America also found pronounced differences in tree transpiration and it was concluded that it is necessary to include sites at different topographic positions for landscape-level analyses or modeling (Loranty et al., 2008; 
Mackay et al., 2010; Angstmann et al., 2012). In our case, we found only moderate variation in oil palm water use across space and time, whereas rubber responded strongly to topographic position and temporal flooding. These differences may be of interest in eco-hydrological assessments of post-forest plantation landscapes.

\section{AUTHOR CONTRIBUTIONS}

The concept and research priorities for this study on rubber trees in Sumatra were developed by $\mathrm{DH}$, in close cooperation with $\mathrm{H}$. Setup and maintenance of the field installations and data collection were performed by $\mathrm{AH}, \mathrm{AR}, \mathrm{FN}$, and AM. Data analysis, plotting, and manuscript writing were mainly carried out by $\mathrm{AH}, \mathrm{AR}, \mathrm{FN}$, and $\mathrm{DH}$, in close cooperation with the other co-authors.

\section{REFERENCES}

Angstmann, J. L., Ewers, B. E., Barber, J., and Kwon, H. (2012). Testing transpiration controls by quantifying spatial variability along a boreal black spruce forest drainage gradient. Ecohydrology 6, 783-793. doi: 10.1002/eco. 1300

Aroca, R., Porcel, R., and Ruiz-Lozano, J. M. (2012). Regulation of root water uptake under abiotic stress conditions. J. Exp. Bot. 63, 43-57. doi: 10.1093/jxb/ err266

Atkinson, C. J., Harrison-Murray, R. S., and Taylor, J. M. (2008). Rapid floodinduced stomatal closure accompanies xylem sap transportation of rootderived acetaldehyde and ethanol in Forsythia. Environ. Exp. Bot. 64, 196-205. doi: 10.1016/j.envexpbot.2008.02.001

Barnes, A. D., Jochum, M., Mumme, S., Haneda, N. F., Farajallah, A., Widarto, T. H., et al. (2014). Consequences of tropical land use for multitrophic biodiversity and ecosystem functioning. Nat. Commun. 5:5351. doi: 10.1038/ ncomms6351

Deo, R. C., Byun, H. R., Adamowski, J. F., and Kim, D. W. (2015). A real-time flood monitoring index based on daily effective precipitation and its application to Brisbane and Lockyer valley flood events. Water Resour. Manag. 29, 4075-4093. doi: 10.1007/s11269-015-1046-3

Drescher, J., Rembold, K., Allen, K., Beckschäfer, P., Buchori, D., Clough, Y., et al. (2016). Ecological and socio-economic functions across tropical land use systems after rainforest conversion. Philos. Trans. R. Soc. B 371:20150275. doi: $10.1098 /$ rstb.2015.0275

Drew, M. C. (1997). Oxygen deficiency and root metabolism: injury and acclimation under hypoxia and anoxia. Annu. Rev. Plant Biol. 48, 223-250. doi: 10.1146/annurev.arplant.48.1.223

Else, M. A., Coupland, D., Dutton, L., and Jackson, M. B. (2001). Decreased root hydraulic conductivity reduces leaf water potential, initiates stomatal closure and slows leaf expansion in flooded plants of castor oil (Ricinus communis) despite diminished delivery of ABA from the roots to shoots in xylem sap. Physiol. Plant. 111, 45-64. doi: 10.1034/j.1399-3054.2001.1110107.x

Ezin, V., Pena, R. D. L., and Ahanchede, A. (2010). Flooding tolerance of tomato genotypes during vegetative and reproductive stages. Braz. J. Plant Physiol. 22, 131-142. doi: 10.1590/S1677-04202010000200007

FAO (2016). FAOSTAT Online Statistical Service: Food and Agriculture Organization of the United Nations (FAO). Available at: http://faostat.fao.org [accessed April 10, 2016].

Fox, J., Vogler, J. B., Sen, O. L., Giambelluca, T. W., and Ziegler, A. D. (2012). Simulating land-cover change in Montane mainland Southeast Asia. Environ. Manag. 49, 968-979. doi: 10.1007/s00267-012-9828-3

Giambelluca, T. W., Mudd, R. G., Liu, W., Ziegler, A. D., Kobayashi, N., Kumagai, T., et al. (2016). Evapotranspiration of rubber (Hevea brasiliensis) cultivated at two plantation sites in Southeast Asia. Water Resour. Res. 52, 660-679. doi: 10.1002/2015WR017755

\section{FUNDING}

This study was supported by a grant from the German Research Foundation (DFG, CRC 990, A02, Z02 and ABS project). AH received a scholarship from the Indonesian-German Scholarship Programme (IGSP) and FN received a scholarship from the China Scholarship Council (CSC).

\section{ACKNOWLEDGMENTS}

We acknowledge support by the Open Access Publication Funds of the University of Göttingen. We would like to thank Heri Junaedi and Andrea Hanf for field support and cooperation, Agusta Herdhata and Surya Tarigan for constructive cooperation, and our field assistants Ali, Bayu, and Ferry for supporting us at all times during the field measurements.

Gonkhamdee, S. (2010). Analysis of Interactions Between Rubber Tree (Hevea brasiliensis Mull. Arg.) and Inter-Crop Roots in Young Plantations of NE Thailand. Ph.D. dissertation, Université d'Avignon, Avignon.

Gouyon, A., de Foresta, H., and Levang, P. (1993). Does 'jungle rubber' deserve its name? An analysis of rubber agroforestry systems in Southeast Sumatra. Agroforest. Syst. 22, 181-206. doi: 10.1007/BF00705233

Granier, A. (1985). Une nouvelle méthode pour la mesure du flux de sève brute dans le tronc des arbres. Ann. For. Sci. 42, 193-200. doi: 10.1051/forest: 19850204

Herrera, A. (2013). Responses to flooding of plant water relations and leaf gas exchange in tropical tolerant trees of a black-water wetland. Front. Plant Sci. 4:106. doi: 10.3389/fpls.2013.00106

Holbrook, N. M., and Sinclair, T. R. (1992). Water balance in the arborescent palm, Sabal palmetto. II. Transpiration and stem water storage. Plant Cell Environ. 15, 401-409. doi: 10.1111/j.1365-3040.1992.tb00990.x

Isarangkool Na Ayutthaya, S., Do, F. C., Pannengpetch, K., Junjittakarn, J., Maeght, J.-L., Rocheteau, A., et al. (2010). Transient thermal dissipation method of xylem sap flow measurement: multi-species calibration and field evaluation. Tree Physiol. 30, 139-148. doi: 10.1093/treephys/tpp092

Jourdan, C., Ferriere, N. M., and Perbal, G. (2000). Root system architecture and gravitropism in the oil palm. Ann. Bot. 85, 861-868. doi: 10.1006/anbo.2000. 1148

Keenan, R. J., Reams, G. A., Achard, F., Freitas, J. V., Grainger, A., and Lindquist, E. (2015). Dynamics of global forest area: results from the FAO global forest resources assessment 2015. For. Ecol. Manag. 352, 9-20. doi: 10.1016/j.foreco. 2015.06.014

Kobayashi, N., Kumagai, T., Miyazawa, Y., Matsumoto, K., Tateishi, M., Lim, T. K., et al. (2014). Transpiration characteristics of a rubber plantation in central Cambodia. Tree Physiol. 34, 285-301. doi: 10.1093/treephys/tpu009

Kotowska, M. M., Leuschner, C., Triadiati, T., Meriem, S., and Hertel, D. (2015). Quantifying above- and belowground biomass carbon loss with forest conversion in tropical lowlands of Sumatra (Indonesia). Glob. Change Biol. 21, 3620-3634. doi: $10.1111 /$ gcb.12979

Kreuzwieser, J., and Rennenberg, H. (2014). Molecular and physiological responses of trees to waterlogging stress: responses of tree to waterlogging. Plant Cell Environ. 37, 2245-2259. doi: 10.1111/pce.12310

Kumagai, T., Tateishi, M., Shimizu, T., and Otsuki, K. (2008). Transpiration and canopy conductance at two slope positions in a Japanese cedar forest watershed. Agric. For. Meteorol. 148, 1444-1455. doi: 10.1016/j.agrformet.2008.04.010

Kume, T., Kenji, T., Komatsu, H., Shinohara, Y., Katayama, A., Ide, J., et al. (2015). Differences in sap flux based stand transpiration between upper and lower slope positions in a Japanese cypress plantation watershed: sap flux in upper and lower slope positions. Ecohydrology 9, 1105-1116. doi: 10.1002/eco.1709

Kume, T., Tsuruta, K., Komatsu, H., Kumagai, T., Higashi, N., Shinohara, Y., et al. (2010). Effects of sample size on sap flux-based stand-scale transpiration estimates. Tree Physiol. 30, 129-138. doi: 10.1093/treephys/tpp074 
Laumonier, Y., Uryu, Y., Stüwe, M., Budiman, A., Setiabudi, B., and Hadian, O. (2010). Eco-floristic sectors and deforestation threats in Sumatra: identifying new conservation area network priorities for ecosystem-based land use planning. Biodivers. Conserv. 19, 1153-1174. doi: 10.1007/s10531-010-9784-2

Loranty, M. M., Mackay, D. S., Ewers, B. E., Adelman, J. D., and Kruger, E. L. (2008). Environmental drivers of spatial variation in whole-tree transpiration in an aspen-dominated upland-to-wetland forest gradient. Water Resour. Res. 44, W02441. doi: 10.1029/2007WR006272

Mackay, D. S., Ewers, B. E., Loranty, M. M., and Kruger, E. L. (2010). On the representativeness of plot size and location for scaling transpiration from trees to a stand. J. Geophys. Res. 115, G02016. doi: 10.1029/2009JG001092

Margono, B. A., Turubanova, S., Zhuravleva, I., Potapov, P., Tyukavina, A., Baccini, A., et al. (2012). Mapping and monitoring deforestation and forest degradation in Sumatra (Indonesia) using Landsat time series data sets from 1990 to 2010. Environ. Res. Lett. 7:034010. doi: 10.1088/1748-9326/7/3/034010

McJannet, D. (2008). Water table and transpiration dynamics in a seasonally inundated Melaleuca quinquenervia forest, north Queensland, Australia. Hydrol. Process. 22, 3079-3090. doi: 10.1002/hyp.6894

Meijide, A., Röll, A., Fan, Y., Herbst, M., Niu, F., Tiedemann, F., et al. (2017). Controls of water and energy fluxes in oil palm plantations: environmental variables and oil palm age. Agric. For. Meteorol. 239, 71-85. doi: 10.1016/j. agrformet.2017.02.034

Miettinen, J., Stibig, H. J., and Achard, F. (2014). Remote sensing of forest degradation in Southeast Asia-Aiming for a regional view through 5-30 m satellite data. Glob. Ecol. Cons. 2, 24-36. doi: 10.1016/j.gecco.2014.07.007

Miyazawa, Y., Tateishi, M., Komatsu, H., Ma, V., Kajisa, T., Sokh, H., et al. (2014). Tropical tree water use under seasonal waterlogging and drought in central Cambodia. J. Hydrol. 515, 81-89. doi: 10.1016/j.jhydrol.2014.04.049

Naumann, R. V. (2015). Exploration of Tropical Landscape Structures by an Unmanned Aerial Vehicle in Sumatra. Master's thesis, Georg-AugustUniversität Göttingen, Göttingen.

Nicolás, E., Torrecillas, A., Amico, J. D., and Alarcón, J. J. (2005). The effect of short-term flooding on the sap flow, gas exchange and hydraulic conductivity of young apricot trees. Trees 19, 51-57. doi: 10.1007/s00468-004-0362-7

Niu, F., Röll, A., Hardanto, A., Meijide, A., Köhler, M., Hendrayanto, et al. (2015). Oil palm water use: calibration of a sap flux method and a field measurement scheme. Tree Physiol. 35, 563-573. doi: 10.1093/treephys/tpv013

O'Grady, A. P., Eamus, D., Cook, P. G., and Lamontagne, S. (2006). Comparative water use by the riparian trees Melaleuca argentea and Corymbia bella in the wet-dry tropics of northern Australia. Tree Physiol. 26, 219-228. doi: 10.1093/ treephys/26.2.219

Ortuño, M. F., Alarcón, J. J., Nicolás, E., and Torrecillas, A. (2007). Water status indicators of lemon trees in response to flooding and recovery. Biol. Plant. 51, 292-296. doi: 10.1007/s10535-007-0058-0

Parent, C., Capelli, N., Berger, A., Crèvecoeur, M., and Dat, J. F. (2008). An overview of plant responses to soil waterlogging. Plant Stress 2, 20-27.

Pezeshki, S. R., and Chambers, J. L. (1985). Stomatal and photosynthetic response of sweet gum (Liquidambar styraciflua) to flooding. Can. J. For. Res. 15, 371-375. doi: 10.1139/x85-059

Röll, A., Niu, F., Meijide, A., Hardanto, A., Hendrayanto, Knohl, A., et al. (2015). Transpiration in an oil palm landscape: effects of palm age. Biogeosciences 12, 9209-9242. doi: 10.5194/bgd-12-9209-2015
Santiago, L. S., Goldstein, G., Meinzer, F. C., Fownes, J. H., and MuellerDombois, D. (2000). Transpiration and forest structure in relation to soil waterlogging in a Hawaiian montane cloud forest. Tree Physiol. 20, 673-681. doi: 10.1093/treephys/20.10.673

Sauer, T. J., Logsdon, S. D., Brahana, J. V., and Murdoch, J. F. (2005). Variation in infiltration with landscape position: implications for forest productivity and surface water quality. For. Ecol. Manag. 220, 118-127. doi: 10.1016/j.foreco. 2005.08.009

Sopharat, J., Gay, F., Thaler, P., Sdoodee, S., Isarangkool Na Ayutthaya, S., Tanavud, C., et al. (2015). A simple framework to analyze water constraints on seasonal transpiration in rubber tree (Hevea brasiliensis) plantations. Front. Plant Sci. 5:753. doi: 10.3389/fpls.2014.00753

Sterling, S. M., Ducharne, A., and Polcher, J. (2012). The impact of global landcover change on the terrestrial water cycle. Nat. Clim. Change 3, 385-390. doi: 10.1038/nclimate1690

Tan, Z. H., Zhang, Y. P., Song, Q. H., Liu, W. J., Deng, X. B., Tang, J. W., et al. (2011). Rubber plantations act as water pumps in tropical China. Geophys. Res. Lett. 38, 24406. doi: 10.1029/2011GL050006

Tromp-van Meerveld, H. J., and McDonnell, J. J. (2006). On the interrelations between topography, soil depth, soil moisture, transpiration rates and species distribution at the hillslope scale. Adv. Water Resour. 29, 293-310. doi: 10.1016/ j.advwatres.2005.02.016

Van der Laan, C., Wicke, B., Verweij, P. A., and Faaij, A. P. C. (2016). Mitigation of unwanted direct and indirect land-use change-an integrated approach illustrated for palm oil, pulpwood, rubber and rice production in North and East Kalimantan, Indonesia. GCB Bioenergy 9, 429-444. doi: 10.1111/gcbb.12353

Whitten, T., Damanik, S. J., Anwar, J., and Hisyam, N. (2000). The Ecology of Sumatra. Singapore: Periplus Edition, Ltd.

Wittmann, C., and Pfanz, H. (2014). Bark and woody tissue photosynthesis: a means to avoid hypoxia or anoxia in developing stem tissues. Funct. Plant Biol. 41, 940-953. doi: 10.1071/FP14046

Yan, X. L., Xi, B. Y., Jia, L. M., and Li, G. D. (2015). Response of sap flow to flooding in plantations of irrigated and non-irrigated triploid poplar. J. For. Res. 20, 375-385. doi: 10.1007/s10310-015-0485-2

Zhao, H. F., Zhao, Y., Zhang, C., Tao, X., and Xu, X. N. (2014). Growth, leaf gas exchange, and chlorophyll fluorescence responses of two cultivars of Salix integra Thunb. to waterlogging stress. J. Agric. Sci. Technol. 16, 137-146.

Ziegler, A. D., Fox, J. M., and Xu, J. (2009). The rubber juggernaut. Science 324, 1024-1025. doi: 10.1126/science. 1173833

Conflict of Interest Statement: The authors declare that the research was conducted in the absence of any commercial or financial relationships that could be construed as a potential conflict of interest.

Copyright (C) 2017 Hardanto, Röll, Niu, Meijide, Hendrayanto and Hölscher. This is an open-access article distributed under the terms of the Creative Commons Attribution License (CC BY). The use, distribution or reproduction in other forums is permitted, provided the original author(s) or licensor are credited and that the original publication in this journal is cited, in accordance with accepted academic practice. No use, distribution or reproduction is permitted which does not comply with these terms. 